\title{
Optimum Conditions for Glutaminase Production by Serratia marcescens N1
}

\author{
Nedhaal S. Zbar, Abdul Wahid B. Al-Shaibani and Hameed M. Jasim \\ College of Science, Al - Nahrain University.
}

\begin{abstract}
Optimum conditions for glutaminase production by Serratia marcescens N1 in glutamine broth medium were studied. Results showed that maximum glutaminase production was achieved when S.marcescens was cultured in production medium supplemented with starch as a sole source for carbon and energy at a concentration of $0.5 \%$, meat extract as a nitrogen source at a concentration of $0.5 \%$, pH8 and inoculated with a count of $2 \times 10^{4} \mathrm{CFU} / \mathrm{ml}$ of fresh bacterial culture, then incubated in a shaker incubator $(150 \mathrm{rpm})$ at $30^{\circ} \mathrm{C}$ for $18 \mathrm{hrs}$. Under these conditions, specific activity of crude glutaminase produced in culture filtrate was $5.8 \mathrm{U} / \mathrm{mg}$ protein.
\end{abstract}

\section{Introduction}

L-glutaminase L-glutamine amidohydrolase (EC: 3.5.1.2) catalyzes the hydrolysis of L-glutamine to L- Glutamic acid and ammonia (1), which plays a major role in the cellular nitrogen metabolism of both prokaryotic and eukaryotic cells (2). Glutaminase is ubiquitous in various organisms, and was widely distributed in plants, animal tissues and microorganisms including bacteria, yeast and fungi (3). In recent years, L-glutaminase has attracted much attention in both pharmaceutical and food industrial applications. In food industry, it was used as a flavor enhancer by increasing glutamic acid content in food through hydrolysis of L-glutamine to L-glutamic acid and ammonia. It was also used in the enzyme therapy for cancer, especially for acute lymphocytic leukemia (4). Another important application of L-glutaminase is in biosensors for monitoring the glutamine levels in mammalian and hybridoma cells (5). Recombinant glutaminase was patented for its activity against cancer and HIV (6). Due to the widely variations in the nutritional requirements among bacteria, numerous media were developed for glutaminase production. Optimum activity conditions for any enzyme in vitro are not necessarily optimum for the same enzyme in vivo, so the components of a medium were determined by microorganism, cost, purification process, waste treatment, and so forth (7). The main objective of this study was to determine the optimum conditions for glutaminase production by Serratia marcescens $\mathrm{N} 1$.

\section{Materials and Methods \\ Microorganism and media}

Serratia marcescens N1 was obtained from a previous study (8). This isolate was maintained on tripticase soya agar medium (Biolife), glutaminase production by this isolate was achieved in a production medium containing (per liter): $2 \mathrm{~g}$ of L-glutamine, $0.05 \mathrm{~g}$ of $\mathrm{MgSO}_{4} .7 \mathrm{H}_{2} \mathrm{O}$ and $1 \mathrm{~g}$ of $\mathrm{K}_{2} \mathrm{HPO}_{4}$ in $1000 \mathrm{ml}$ deionized distilled water (9).

\section{Enzyme assay}

Assay of glutaminase was achieved according to Novak and Philips (10), by incubating $200 \mu \mathrm{l}$ of the crude enzyme and $50 \mu \mathrm{l}$ of reaction mixture containing $0.1 \mathrm{M}$ glutamine dissolved in $0.02 \mathrm{M}$ phosphate buffer (pH8) in a shaker incubator at $37^{\circ} \mathrm{C}$ for $30 \mathrm{~min}$. Reaction was stopped by adding $5 \mathrm{ml}$ of mixture consisted of $1 \%$ phenol and $0.005 \%$ nitroprusside, then $5 \mathrm{ml}$ of $0.5 \%$ sodium hydroxide was added. Test tubes were reincubated in a shaker water bath (100 cycle/min.) at $37^{\circ} \mathrm{C}$ for $20 \mathrm{~min}$. Absorbance was measured at $595 \mathrm{~nm}$, then enzyme activity was measured according to ammonium standard curve. Activity unit was defined as the amount of enzyme required to liberate $1 \mu \mathrm{mol}$ of ammonium in one minute under experimental conditions.

\section{Protein concentration}

Protein concentration in culture medium was determined according to Lowery (11) by using folin reagent and Bovine serum albumin standard solution. 


\section{Optimization of glutaminase production}

Optimum conditions for glutaminase production by Serratia marcescens N1 was carried out aerobically by inoculating fifty $\mathrm{ml}$ of the production medium in to $250 \mathrm{ml}$ Erlenmeyer flasks with $1 \%$ of mid-exponential phase culture of Serratia marcescens N1 and incubated at $30^{\circ} \mathrm{C}$ for $24 \mathrm{hrs}$. Optimum conditions included the type and concentration of carbon and nitrogen sources, $\mathrm{pH}$ medium, incubation temperature, incubation period, inoculum size and agitation speed.

\section{Effect of carbon source}

Six carbon sources (starch, lactose, fructose, glucose, maltose or sucrose) were used as a sole source for carbon and energy to determine the optimum on suitable for glutaminase production by S.marcescens N1. These carbon sources were added to the production medium (glutamine broth medium) at a concentration of $0.5 \%$ and six concentrations of starch $(0.5,1,1.5,2,2.5$ or $3 \%$ respectively).

\section{Effect of nitrogen source}

Five nitrogen sources were used for this purpose. These nitrogen sources include meat extract, peptone, yeast extract, ammonium nitrate and casein that were added to the production medium in a concentration of $0.5 \%$. and various concentrations $(0.5,1,1.5$, $2,2.5$ and $3 \%$ ) of the most efficient source of nitrogen (meat extract).

\section{Effect of inoculum size and $\mathbf{p H}$}

Six inoculum sizes were used to optimize glutaminase production. They were $2 \times 10^{3}$, $2 \times 10^{4}, 2 \times 10^{5}, 2 \times 10^{6}, 2 \times 10^{7}$, or $2 \times 10^{8} \mathrm{cfu} / \mathrm{ml}$ respectively, and used to inoculate the production medium separately. Also different $\mathrm{pH}$ values were studied optimize glutaminase production by S.marcescens N1,

\section{Effect of incubation temperature and incubation period}

In this study different incubation temperatures $(15,20,25,30,35,40,45$ or $50^{\circ} \mathrm{C}$ ) were used and also different incubation periods $(6,12,18,24,30,36$ or $48 \mathrm{hrs})$ were applied.

\section{Effect of agitation}

Effect of agitation on glutaminase production by S.marcescens N1 was determined by incubating bacterial cultures in a shaker incubator at different speeds of agitation $(50,100,150$, or $200 \mathrm{rpm})$.

\section{Results and Discussion \\ Optimization of glutaminase production Effect of carbon source}

Results mentioned in Fig.(1) showed that maximum glutaminase production was achieved when starch was used as a sole source for carbon and energy because enzyme specific activity in crude filtrate of S.marcescens $\mathrm{N} 1$ reached the maximum value (1.3 U/mg), while the specific activity was less when the production medium was supplemented with other carbon sources. By using this carbon source, glutaminase specific activity in crude filtrate of N1 culture reached $1.3 \mathrm{U} / \mathrm{mg}$. Other results showed that glucose was less effective in glutaminase production because enzyme specific activity in crude filtrate of N1 culture was $0.42 \mathrm{U} / \mathrm{mg}$. Prusiner (12) reported that a higher concentration of glucose supported better growth and biomass of S.marcescens but enzyme production was suppressed at a glucose concentration of $1 \%$ and above. This may be due to the catabolic repression of the enzyme.

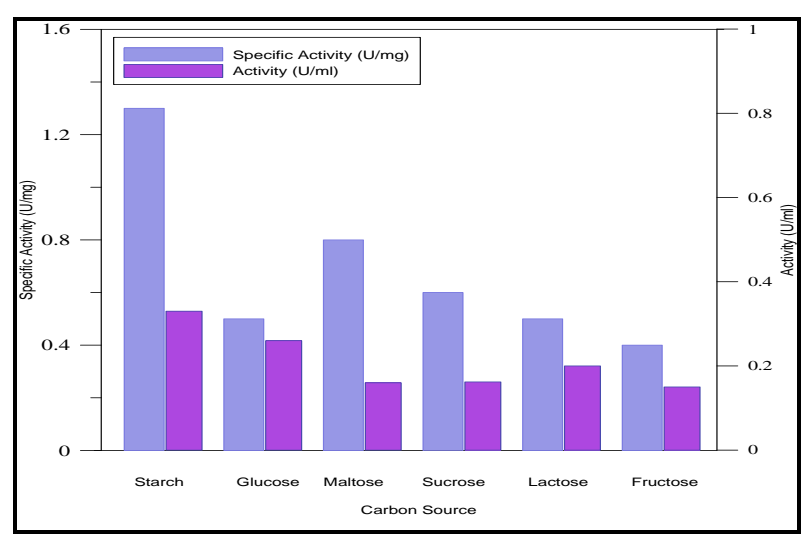

Fig. (1) Effect of carbon source on glutaminase production by S.marcescens N1 after incubation at $37^{\circ} \mathrm{C}$ for $24 \mathrm{hrs}$.

\section{Effect of carbon source concentration}

Results illustrated in Fig.(2) showed that glutaminase production varied according to the concentration of starch. Maximum production of glutaminase was achieved when the 
production medium was supplemented with $0.5 \%$ starch. At this concentration enzyme specific activity reached $1.3 \mathrm{U} / \mathrm{mg}$, and then specific activity decreased with the increase of starch concentration.

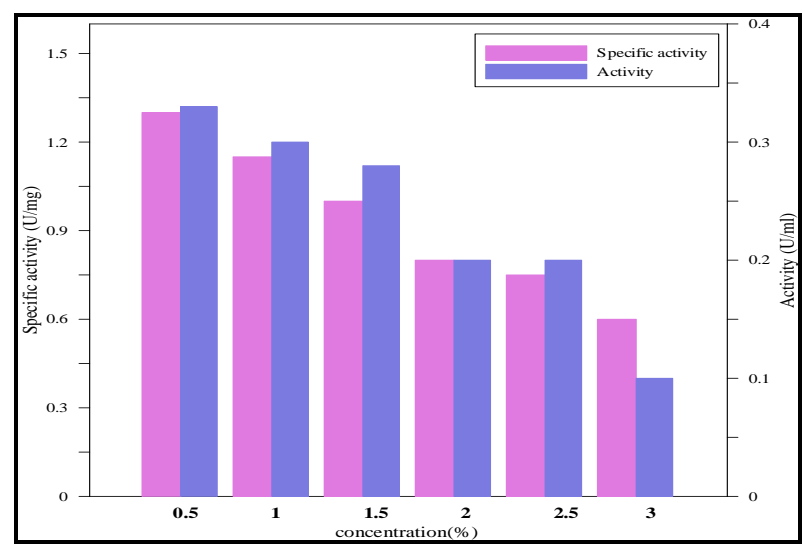

Fig. (2) Effect of starch concentration on glutaminase production by $S$. marcescens $N 1$ after incubation for $24 \mathrm{hrs}$ at $37^{\circ} \mathrm{C}$.

\section{Effect of nitrogen source}

Results illustrated in Fig.(3) showed that production of glutaminase by $S$. marcescens $\mathrm{N} 1$ varied according to the type of nitrogen source. Hence maximum glutaminase production was achieved by adding meat extract to the production medium. Enzyme specific activity in crude filtrate of S.marcescens N1 recorded $1.4 \mathrm{U} / \mathrm{mg}$ using this nitrogen source, while specific activity was less when the production medium was supplemented with other nitrogen sources.

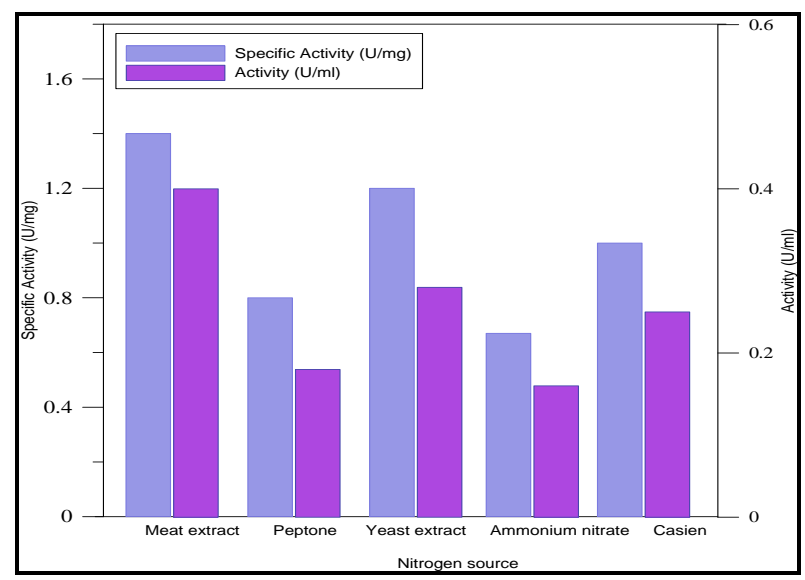

Fig.(3) Effect of different nitrogen sources on glutaminase production by $S$. marcescens N1 after incubation for $24 \mathrm{hrs}$ at $37^{\circ} \mathrm{C}$.
In general, glutamine has an important role in increasing glutaminase production to two foldes compared with other sources of nitrogen such as ammonium ions and glutamate (12). On the other hand, Keerthi et al., (13) found that production of glutaminase by $B$. bassiana required $1 \%$ of yeast extract, $9 \%$ of ammonium chloride and $2 \%$ methionine to get higher productivity.

\section{Effect of nitrogen source concentration}

Results indicated in Fig.(4) showed that maximum glutaminase productivity was obtained when meat extract was supplemented to the production medium at a concentration of $0.5 \%$. At this concentration, glutaminase specific activity in culture filtrate of S.marcescens $\mathrm{N} 1$ reached $1.4 \mathrm{U} / \mathrm{mg}$. Meat extract at this concentration $(0.5 \%)$ provide the most growth requirements for bacterial growth and production of secondary metabolites (14).

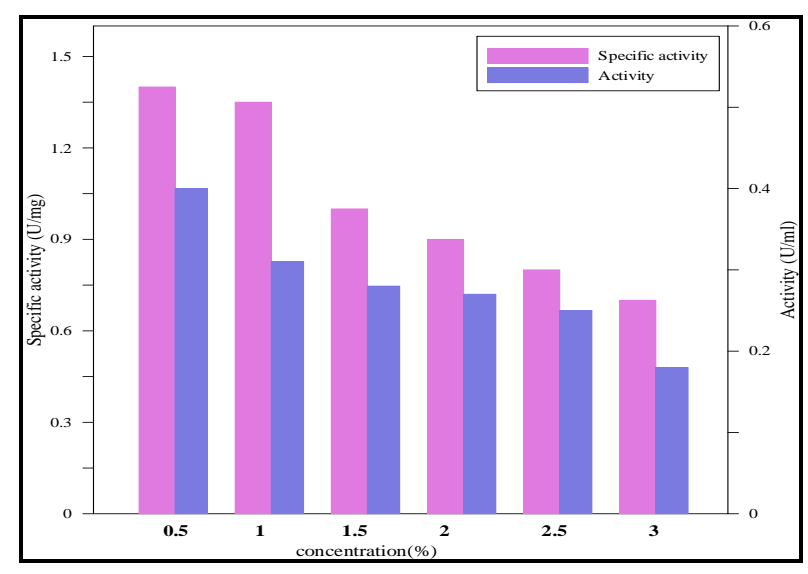

Fig. (4) Effect of meat extract concentration\% on glutaminase production by $S$. marcescens $N 1$ after incubation at $37^{\circ} \mathrm{C}$ for 24 hrs.

\section{Effect of inoculum size}

Results illustrated in Fig.(5) showed that production of glutaminase by S.marcescens N1 was affected by the ionculum size of microorganism. It was found that glutaminase production increased slightly with increasing inoculum size to $2 \times 10^{4} \mathrm{cfu} / \mathrm{ml}$, then glutaminase production decreased gradually. Maximum productivity was obtained when the production medium was inoculated with $2 \times 10^{4} \mathrm{CFU} / \mathrm{ml}$ that caused an increase in enzyme specific activity to $1.5 \mathrm{U} / \mathrm{mg}$, hence decreasing glutaminase production at higher inoculum size (more than $2 \times 10^{4} \mathrm{cfu} / \mathrm{ml}$ ). It 
may be attributed to the high density of bacterial cells, competition on nutrients and increasing toxic secondary metabolites which inhibit growth cells, leading to a decrease in enzyme production (15). In other study, it was found that $2.3 \times 10^{4} \mathrm{CFU} / \mathrm{ml}$ of inoculum size was the most efficient for glutaminase production by Vibrio choerae (16). The inoculum ratio to production medium that gives maximum productivity of enzymes differs according to the type of microorganism and cultural conditions (17).

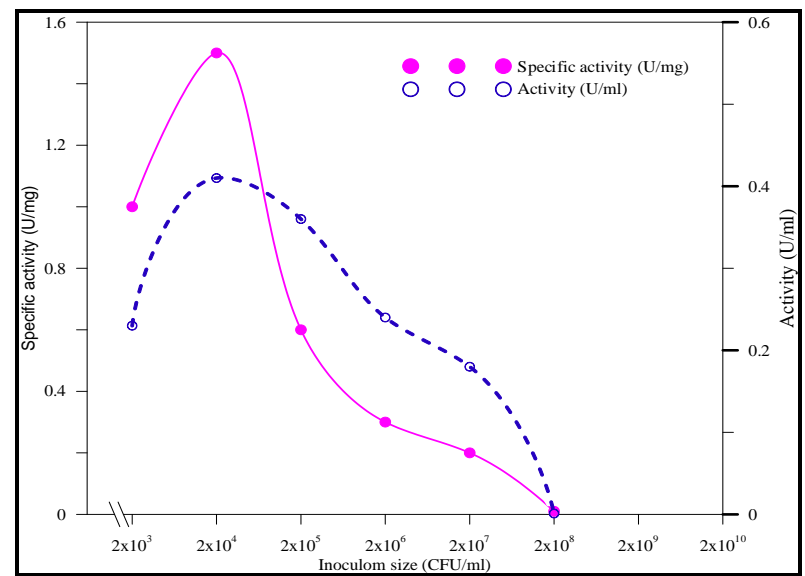

Fig.(5) Effect of inoculums size on

glutaminase production by $S$. marcescens $N 1$ after incubation at $37^{\circ} \mathrm{C}$ for $24 \mathrm{hrs}$.

\section{Effect of medium pH}

Results shown in Fig.(6) indicate that maximum glutaminase production was obtained when the $\mathrm{pH}$ value of the production medium was adjusted to 8 , since enzyme specific activity in the culture medium reached $1.5 \mathrm{U} / \mathrm{mg}$. This result is in agreement with Al-Naima (17), who noticed that the maximum glutaminase production by Vibrio cholera $\mathrm{S} 1$ was obtained when the production medium was adjusted to alkaline $\mathrm{pH}$. A decrease or increase in hydrogen ions $\left(\mathrm{H}^{+}\right)$causes $\mathrm{pH}$ changes in the culture medium which may lead to drastic changes in the three-dimensional structure of proteins because of the competition of $\mathrm{H}^{+}$and/or.

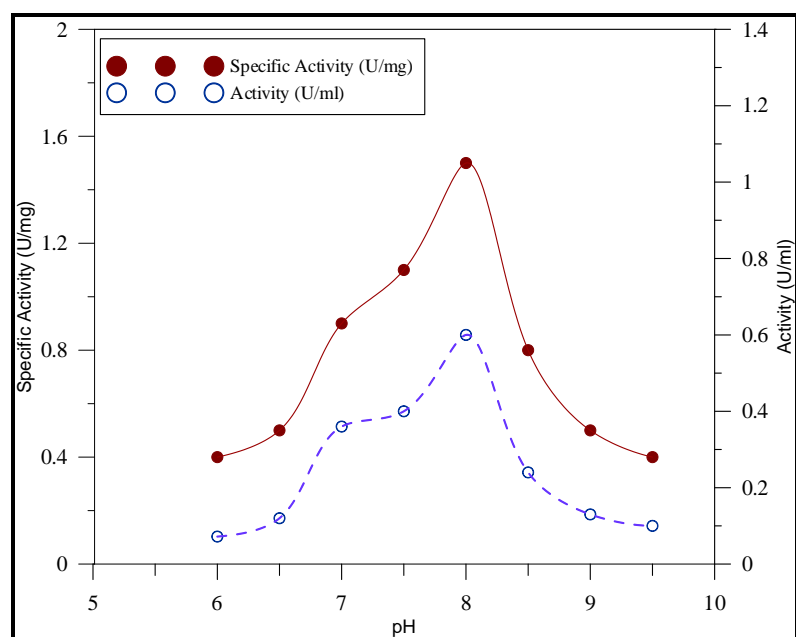

Fig.(6) Effect of medium pH on glutaminase production by S.marcescens N1 after incubation at $37^{\circ} \mathrm{C}$ for 24 hours.

$\mathrm{OH}^{-}$with hydrogen bonds and ionic bonds in an enzyme structure resulting in enzymes denaturation as speculated by Tortora (18).

The effect of $\mathrm{pH}$ on enzyme production was due to its role in the solubility of the nutritional substances and its effect on the ionizable state of the substrate and its availability to the microorganism, in addition to its effect on the stability of the produced enzyme (19).

\section{Effect of incubation temperature}

For any enzymatic reaction, elevation of temperature below or above the optimal will drastically reduce the rate of reaction, hence the incubation temperature usually affects growth of microorganism and glutaminase production (20). Results illustrated in Fig.(7) showed that maximum production of glutaminase was obtained when the culture medium was incubated at $30^{\circ} \mathrm{C}$. Under these conditions, glutaminase specific activity reached $1.7 \mathrm{U} / \mathrm{mg}$. These results were in agreement with that obtained by Green Wood et al (21), who found that the $30^{\circ} \mathrm{C}$ was relevant for glutaminase production from Serratia marcescens . 


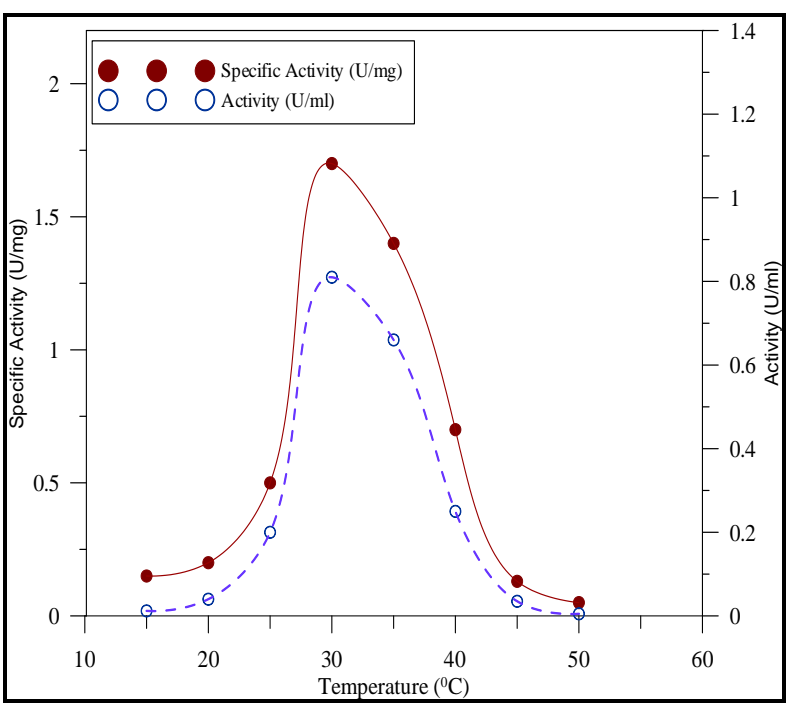

Fig.(7) Effect of incubation temperature on glutaminase production by $S$. marcescens N1 after incubation for $24 \mathrm{hrs}$.

In other studies, it was found that the optimum growth temperature for Xanthomonas spp for glutaminase production was $30^{\circ} \mathrm{C}$, while the optimum for glutaminase production from E.coli, V.cosicola and Vibrio cholerae was $37^{\circ} \mathrm{C}$ respectively $(17,22$, and 23).

\section{Effect of incubation period}

Results indicated in Fig.(8) showed that enzyme production was initiated after the first $6 \mathrm{hrs}$ of incubation with a gradual increase in its productivity with an increasing in the incubation period. Enzyme specific activity reached its maximum $(4 \mathrm{U} / \mathrm{mg}$ ) after $18 \mathrm{hrs}$ of incubation, then it began to decrease slowly recording $0.3 \mathrm{U} / \mathrm{mg}$ after $48 \mathrm{hrs}$ of incubation. Enzyme production decreased after $48 \mathrm{hrs}$ of incubation, which may be due to the adverse effect of metabolism products accumulated in culture medium that produced continuously during the time course of bacterial growth (24).

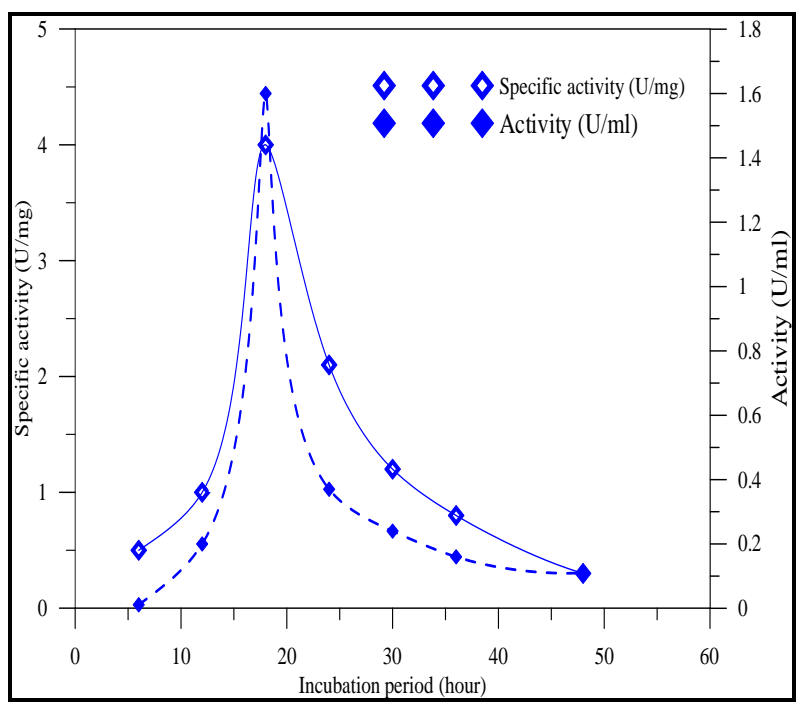

Fig.(8) Effect of incubation period on glutaminase production by S.marcescens N1 after incubation at $30^{\circ} \mathrm{C}$.

In another study, it was found that optimum asparaginase production produced by $S$. marcescens was obtained after $18 \mathrm{hrs}$ of incubation (25).

\section{Effect of agitation}

Results illustrated in Fig.(9) showed that a gradual increase in glutaminase production starting from $1.5 \mathrm{U} / \mathrm{mg}$ (in static state) reaching its maximum $(5.8 \mathrm{U} / \mathrm{mg})$ when the culture medium was incubated at $150 \mathrm{rpm}$, then it began to decrease with increasing the agitation speed. Results are in agreement with (26 and 27) who found that aeration and oxygen are important factors in glutaminase production from different microorganisms.

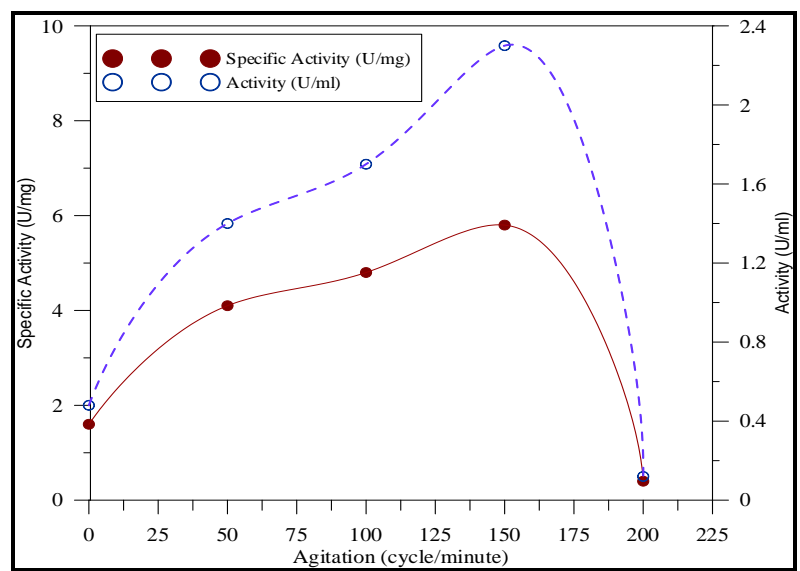

Fig.(9) Effect of agitation on glutaminase production by S.marcescens N1 after incubation in shaker incubator at $30^{\circ} \mathrm{C}$ for 18 hours. 


\section{References}

[1] Oshima, M. Yamamto, T. and Kenji, S. (1976). Further characterization of glutaminase isozymes from Pseudomonas aeruginosa. J. Argic. Biol. Chem., 40(11), 2251-2256.

[2] Sivakumar, K. Sahu, M. K. Manivel, P. R. and Kannan, L. (2006). Optimum Conditions for L-glutaminase production by Actinomycete strain isolated from estuarine fish. Indian J. Exper. Biol., 44: 256-258.

[3] Prabhu G.N. and Chandrasekaran M., (1997). Impact of process parameters on 1glutaminase production by marine Vibro costicola under solid state fermentation using polystyrene as inert support, Biocheml., 32(4): 285-289.

[4] Bhalla, T. C.; Sharma, M. and Sharma, N. (2007). Microbial production of flavors and fragnases; Fats and Oils; DYES; Bioplastcs; Polysaccharides; pharmacology active substances from marine microbes; Anticancer agents and microbial biotransformation. J. App. Microbiol.

[5] Balagurunthan, R. Radhakrishnan, M. Somasundaram, S.T.(2010). L-glutaminase producing Atinomycetes from marine sediments - selective isolation, semiquantitative assay and characterization of potential strain. Aus. J. of Basic and Appl. Sciences., 4:5: 698-705.

[6] Sabu, A., Keerth, T. R., Rajeev, S. and Kandersekran, M.(2000). L- glutaminase production by mrine Beauveria under solid state fermentation. Process.Biochemich., 35:705.

[7] Prakash, P. J. Poorani, E. Anantharaman, P. and Balasubramaniam, T. (2009). L-Glutaminase production and the growth of marine bacteria. J. Microbiol.,:4:(4): 168-172.

[8] Zbar, N.S. (2011). Optimization and improvement of glutaminase production by Serratia marcescens N1. PhD dissertation, College of Science, Al-Nahrain Univ.

[9] Beck,J.V.(1971). Enrichment culture and isolation techniques particularly for aerobic bacteria.In:Methods in Enzymology.

[10] Novak, E. K. and Philips. A. W. (1974). L-Glutamine as a substrate for 1- asparaginase from Serratia marcescens. J. Bact., 117(2): 593-600.

[11] Lowery, O. H.; Rosenbourgh, N. J.; Farr, A.L. and Randall, R. J. (1951). Protein measurement with Folin-Phenol reagent. $J$. Biol. Chem., 193:265-275.

[12] Prusiner, S.; (1975). Regulation of glutaminase level in Escherichia coli. J. Bacteriol., 123(3): 992-999.

[13] Keerthi, T. R; Suresh, P.V.; Sabu, A., Raseevkumar, S. and Chanrasekaren, M. (1999). Extracellular production of 1glutaminase by alkalophilic Beauvera bassana BTMFS 10 isolated from marine sediment. World J. of Microb. and Biotech., 15: 751-752.

[14] Long, S.; Mothibeli, M.A.; Robb, F.T. and Woods, D.R.(1981). Rgulation of extracellular alkaline activity by histidine in collagenolytic Vibrio alginolyticus strains. J. Gen. Microbiol., 127: 193-199.

[15] Rose, A. H. (1976). Chemical Microbiology: An introduction to microbial physiology. ( $3^{\text {rd } E d .) . ~ B u t t e r ~}$ Worths, London. Boston.

[16] Prusiner, S.; (1975). Regulation of glutaminase level in Escherichia coli. J. Bacteriol., 123(3): 992-999.

[17] Al-Naima, S. (2007). Production and characterization of glutaminase from locally isolated Vibrio cholerae (NAG). $\mathrm{PhD}$ Thesis. Baghdad University.

[18] Tortora, G. J.; Funke, B. R. and Case, C. L. (2004). Microbiology. ( $8^{\text {th }}$ ed.). Pearson Education, Inc. San Francisco. New York

[19] Bull, A. and Bushnel, M. E.(1976). Environmental control of fungal growth. In: The filamentous fungi (eds. Smith, J. E. and Berry, D. E.), 2P: 1-26, Edward Arnold, London.

[20] Novak, E. K. and Philips. A. W. (1974). L-Glutamine as a substrate for 1asparaginase from Serratia marcescens. J. Bacteriology, 117(2): 593-600.

[21] Greenwood, D.; Slack, R. and Peutherer, J. (2002). Medical microbiology: A guide to microbial infections: Pathogeneisis, immunity, laboratory diagnosis and control $\left(16^{\text {th }}\right.$ ed.). Toronto, ON: Churchill Livingstone.

[22] Bera, A. K. Sihong, C., Janet, L. S. and Howard, Z. (2000). Temperature- 
Dependent function of the glutamine phosphoribosylepyrophosphate amidotransferase ammonia channel and coupling with Glycinamide Ribonucleutide Synthetase on a hyperthermophile. J. of Bact., 182:3734-3739.

[23] Adamczar, M. and Krishina, S. H. (2004). Enzyme for efficient biocatalyst. J. Food Technol. Biotechnol. 42: 251-264.

[24] Heinman, B. and Haward, A.J. (1969). Production of neoplastic tumor inhibitory enzyme 1-asparaginase by submerged growth of Serratia marcescens. J. Applied Microb., 18:550-554.

[25] Abdel Hameed, A. M. (2005). Production of 1-asparaginase enzyme from local isolates of Serratia and determination of condition affected enzyme production. M.Sc Thesis. Baghdad University

[26] Imada, A.; Igarasi. S.; Nakahama, K. and Isono, M. (1973). Asparaginase and glutaminase activities of micro-organism. J. General Microbiol. 76: 85-99.

[27] Cook, W. R.; Hoffman, J. H. and Bernlohr, R. W. (1981). Occurrence of an inducible glutaminase in Bacillus licheniformis. J. of Bacteriol. 148(1): 365367.

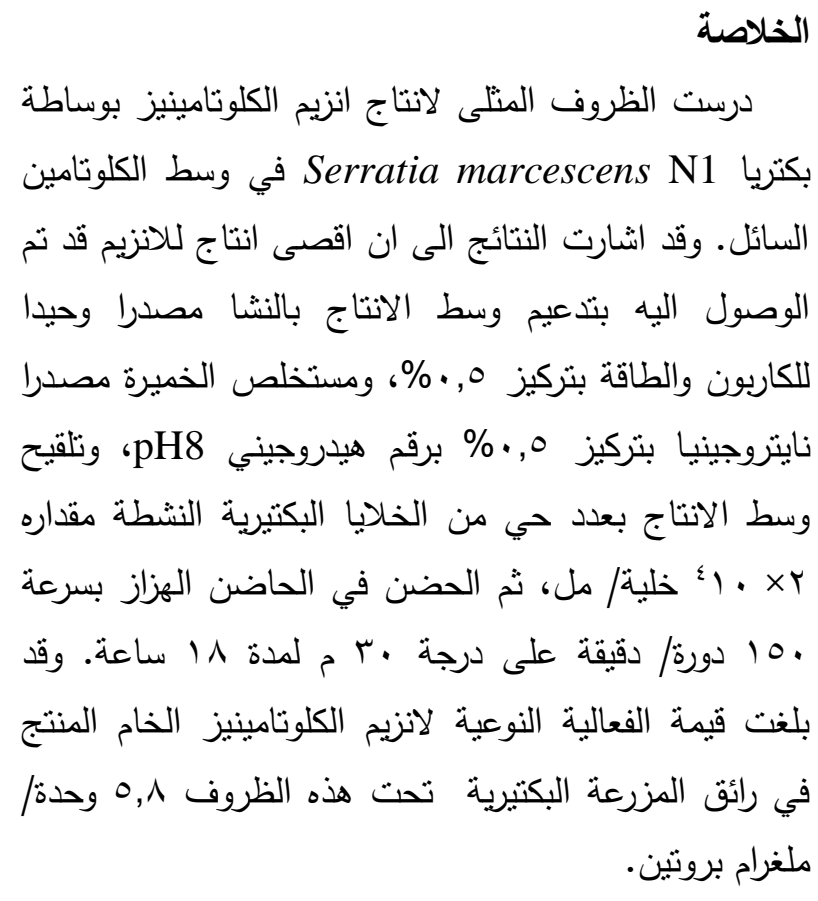

